\title{
Preparation of Sea Cucumber (Holothuria scabra) Powder: Effect of Pre-treatment on Its Nutritional, Antioxidant Activity and Morphological Characteristics
}

\author{
Ansharullah Ansharullah ${ }^{1, *}$, Andi Besse Patadjai ${ }^{2}$, Asranudin Asranudin ${ }^{1}$, and \\ Tamrin Tamrin ${ }^{1}$ \\ ${ }^{1}$ Department of Food Science \& Technology, Faculty of Agriculture, Universitas Halu Oleo, Kendari, Indonesia. \\ ${ }^{2}$ Department of Fisheries Processing Technology, Faculty of Fisheries \& Marine Sciences, Universitas Halu Oleo, \\ Kendari, Indonesia. \\ *Corresponding author. Email: aansharullah@gmail.com
}

\begin{abstract}
Sea cucumber (Holothuria scabra) has a prospect of being one of the nutritious ingredients because it contains complete nutrients, including carbohydrates, essential fatty acids and amino acids, as well as several bioactive components that are believed to have functions as antioxidants, antibacterial, anti-fungal, and anticoagulant. The application of sea cucumber products in the food formulation may be expanded if it is made in the form of powder. This study was aimed to evaluate the application of three pre-treatment in preparing sea cucumber powder, and evaluated the effects on its nutritional content, antioxidant activity, and morphological properties. Three different types of ingredients, namely yam (Dioscorea hispidia Dennst) tuber extract, $\mathrm{NaHCO}_{3}$ solution, and papaya leaf extract, were added to the fresh sea cucumbers. Then, they were heated at $70^{\circ} \mathrm{C}$ for 20 minutes in sea water, smoked, dried, and ground into powder. The results showed that the nutritional content of sea cucumber flour that was given papaya leaves extract had a higher protein content $(59.33 \%)$ and higher ash content $(14.71 \%)$ compared to the other treatments. The pre-treatment with papaya leaves extract had also given the strongest antioxidant activity. The morphological characteristics were observed with Scanning Electron Microscope (SEM).
\end{abstract}

Keywords: Papaya leaf, Sea cucumber powder, Yam tubers extract.

\section{INTRODUCTION}

Sea cucumber, as marine natural resources, had been proven in many scientific studies to have several health beneficial effects, such as wound healing, neuroprotective, antitumor, anticoagulant, antimicrobial, and antioxidants [1][2][3][4][5]. Holothuria scabra as a species of sea cucumber found in many areas of coastal waters has been utilized as medicine ingredients, and has been proved to have no toxic substances [6][7][8]. This species of sea cucumber might contain new fuctional substances, which might be developed and incorporated in the products of food and pharmaceutical industries [6]. This certainly would improve its economical values.

To expand its use in various food and pharmaceutical formulation, an attempt may be made by altering into the powder form [9]. However, the process of powder making might alter its nutritional characteristics and antioxidant activity. Various method in preparing the sea cucumber powder have been reported. Research by Latif et al [10] prepared the sea cucumber powder with different salt concentration and boiling time, which resulted in a fairly high nutritional content. Karnila et al. [11] reported that the ash content of fresh sea cucumbers was on average $12.52 \%$. The 
high ash content is thought to be due to the presence of cuticle layer in the sea cucumber body wall.

In another study, the papaya leaves have been used to facilitate the process of removing the lime layer on the skin of sea cucumbers [12]. Removal of the lime layer traditionally also may be done through the use yam tubers extract [8]; while $\mathrm{NaHCO}_{3}$ (sodium bicarbonate) may also be able to remove the lime layer on sea cucumbers. This research was aimed to study the effect of the pre-treatment methods, i.e., yam tuber extract, $\mathrm{NaHCO}_{3}$ and papaya leaves extract, on the nutritional and functional properties of sea cucumber powder.

\section{MATERIALS AND METHODS}

\subsection{Materials}

Sea cucumber of Holothuria scabra as the main material in this study was obtained from the local fisherman in Toronipa, Konawe, Southeast Sulawesi, Indonesia. The other materials used were yam (Dioscorea hispidia Dennst) tubers extract, chopped papaya leaves, and 5\% NaHCO3 solution. All chemicals used were in analytical grade.

\subsection{Pre-treatments in Sample Preparation}

The preparation of samples was done by following the procedure, including eviscerating the fresh sea cucumber, washing it with distilled water, and removing its lime layer on the surface of the skin by applying three different methods, i.e. P1: addition of tuber extract of Dioscorea hispida; P2: addition of $\mathrm{NaHCO}_{3}$ solution; P3: addition of chopped papaya leaves. In each treatment, the sample was then soaked for 20 minutes in the sea water at the temperature of $70^{\circ} \mathrm{C}$. The sample was then smoked, oven-dried for 6 hours at $60^{\circ} \mathrm{C}$, and processed into powder for further analysis.

\subsection{Analysis of Nutritional Properties}

The method of AOAC [13] was employed in measuring the contents of moisture, protein, fat, and ash. Meanwhile the content of carbohydrate was measured by calculating the difference between 100 and the total amount of water, fat, protein, and ash.

\subsection{Analysis of Antioxidant Activities}

A method of Banerjee et al. [14] was used in maesuring the antioxidant activity by using 1, 1diphenyl-2-picrylhydrazyl (DPPH) as free radicals. Ethanol was used in extracting the samples. About 5 gram of wet sample was cut into small pieces (about 1 $\mathrm{cm}$ in size). The samples was then blended and put into an erlenmeyer and soaked with $100 \mathrm{~mL}$ of methanol for one hour. The resulted solution was then be strained and the filtrate was evaporated using a rotary evaporator at $40^{\circ} \mathrm{C}$. The solid dried extract was then taken into a vial for analysis. The test starting with the making of a series of concentrations, namely 50, 100, 150, 250, 500, 7500 ppm. Each series of concentration of $1 \mathrm{~mL}$ was added 1 $\mathrm{mL}$ of DPPH $0.25 \mathrm{mM}$ solution and $3 \mathrm{ml}$ of ethanol. Then, the samples and DPPH were mixed gently for 1 minute then incubated for 30 minutes in the dark room and room temperature. The absorbance of the mixture was then quantified using the Shimadzu Mini-UV U1240 Spectrophotometer at a wavelength of $513 \mathrm{~nm}$. Inhibition Concentration $\left(\mathrm{IC}_{50}\right)$ values were calculated as the number of sample concentrations to reduce the DPPH concentration by $50 \%$. Percentage inhibition was calculated by formula:

$$
\begin{gathered}
\text { \%Inhibition }= \\
\frac{\text { Absorbance of blank }- \text { Absorbance of DPPH }}{\text { Absorbance of blank }} \times 100 \%
\end{gathered}
$$

\subsection{Morphological Properties}

The physical morphology of sea cucumber flour were observed using a Scanning Electron Microscope (SEM) TESCAN $20 \mathrm{KV}$, with magnification of 500.

\section{RESULTS AND DISCUSSION}

\subsection{Nutritional Composition}

The nutritional content of the samples was affected by the pre-treatment applied during processing of sea cucumber, as indicated in Table 1 . The moisture content of the product prepared with using $\mathrm{NaHCO}_{3}$ had a significantly higher. In general, the pre-treatment method of using yam tuber extracts and papaya leaves extract has resulted in a higher ash content. This indicated that the use of these two methods was not as effective as using $\mathrm{NaHCO}_{3}$. The fat content of products from these three different methods was not significantly different. Product protein content was higher in the method of using papaya leaves extracts, compared to the other two methods. This was thought to be due to the protease content of papaya leaves which may have open up the layer of sea cucumber body wall. 
Table 1. Moisture, protein, fat, ash, and carbohydrate content of sea cucumber powder produced with various pretreatment methods.

\begin{tabular}{|l|c|c|c|}
\hline \multirow{2}{*}{ Content of (\%) } & \multicolumn{3}{|c|}{ Pre-treatment of sea cucumber with } \\
\cline { 2 - 4 } & Yam tuber extract & $\mathrm{NaHCO}_{3}$ & Papaya leaves extract \\
\hline Moisture & $13.49 \pm 0.41$ & $16.99 \pm 0.87$ & $14.89 \pm 0.51$ \\
\hline Protein & $53.18 \pm 0.55$ & $56.29 \pm 0.77$ & $59.33 \pm 0.85$ \\
\hline Fat & $4.51 \pm 0.54$ & $4.33 \pm 0.41$ & $4.75 \pm 0.52$ \\
\hline Ash & $13.89 \pm 0.14$ & $11.75 \pm 0.39$ & $14.71 \pm 0.34$ \\
\hline Carbohydrate by difference & $14.93 \pm 0.28$ & $10.64 \pm 1.51$ & $6.32 \pm 1.63$ \\
\hline
\end{tabular}

\subsection{Antioxidant Activity}

Antioxidant activity of the samples was also affected by the pre-treatment method utilized in the processing stages. As shown in Figure 1, the papaya leaves treatment method produces the product with the strongest antioxidant activity ( $\mathrm{IC}_{50}$ of 98.75$)$. While the other two methods has moderate antioxidant activity. The use of such chemical as $\mathrm{NaHCO}_{3}$ might have reduced the antioxidant activity as shown in Figure 1. The strength of antioxidant activity may be judged from the value of $\mathrm{IC}_{50}$. Very strong antioxidant activity was obtained from the samples with the $\mathrm{IC}_{50}$ value of less than 50 ppm (category 1 ). The $\mathrm{IC}_{50}$ value of between 50 $100 \mathrm{ppm}$ was categorized as strong (category 2), moderate if the $\mathrm{IC}_{50}$ value was between $100-150 \mathrm{ppm}$ (category 3). A weak antioxidant activity was identified if the $\mathrm{IC}_{50}$ value was between $150-200 \mathrm{ppm}$ (category 4) and very weak if the $\mathrm{IC}_{50}$ value was more than $200 \mathrm{ppm}$ (category 5) [15].

The main antioxidant identified in the sea cucumber was from phenolic group, as it has been researched in various studies [16][17], The others were from steroids and alkaloids groups [17][18]. High-performance liquid chromatographic analysis of the sea cucumber mixed extract was revealed in the presence of some phenolic components, such as chlorogenic acid, pyrogallol, routine, coumaric acid, catechin, and ascorbic acid [3].

Some of the compounds contained in sea cucumbers have been scientifically proven to have antioxidant properties that could reduce free radicals and prevent various degenerative diseases caused by excess free radicals. Compounds contained in sea cucumbers include lectins [19], sterols, tri-terpene glycosides [20], chondroitin, chondroitin sulfate E [21], vitamin B1, B2, B6, A, C, D, and E, amino acids, fatty acids (myristate, palmitate, stearic, docosahexesaenate (DHA), eicosapentaenate (EPA), etc.), carotenoids, flavonoid compounds and polyphenols.[17]. A study by Althunibat et al.[22] had proved that water extracts from sea cucumbers with different species namely Holothuria scabra, Holothuria leucospilota and Stichopus chloronotus showed a higher free radical scavenging ability of water extract than those of organic extract. Extracts of Holothuria scabra with cold extraction gave a total phenolic content of $4.85 \mathrm{mg}$ GAE / $g$ while the organic extract of $1.53 \mathrm{mg} \mathrm{GAE} / \mathrm{g}$.

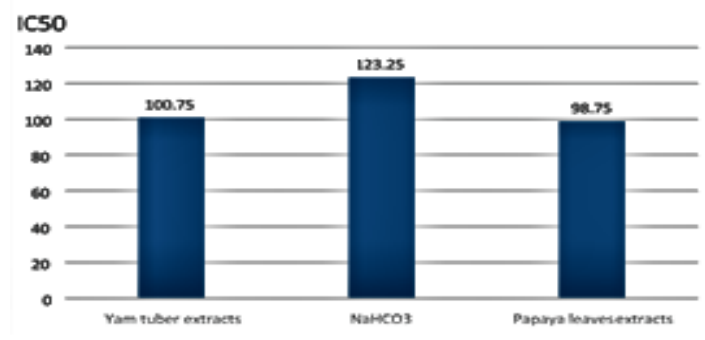

Figure 1. Antioxidant activity of sea cucumber powder processed under different pre-treatment method with yam tuber extract, $\mathrm{NaHCO}_{3}$, and papaya leaves extracts. 




(a)

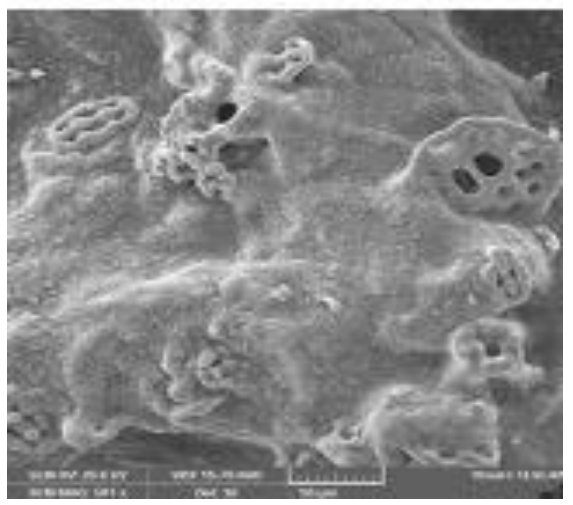

(b)

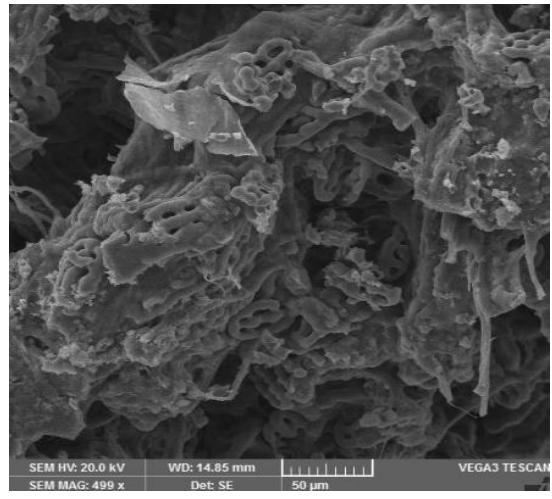

(c)

Figure 2. The effect of pre-treatment method with: (a) yam tuber extracts, (b) $\mathrm{NaHCO}_{3}$, and (c) papaya leaves extract on the physical morphology of the sea cucumber powder by using Scanning electron micrograph of 500 magnification

\subsection{Electron Scanning Micrograph Properties}

The physical morphology of sea cucumber powder were assessed by using Scanning Electron Microscope (SEM). The observation was intended to assess the effect of the pre-treatment method on the morphological structure of the powder produced. As indicated in Figure 2 , most damage of the physical structure of the products was occurred in the papaya leaves method; while the yam tuber extract method shows minimal structural damage.

More structural damage to flour produced from this papaya leaves methods will have the potential to facilitate if the product is utilized in the food and pharmaceutical product formulations, and therefore interactions various food components will be easier to occur.

\section{CONCLUSION}

The use of pre-treatment method in preparation of sea cucumber powder had affected mostly the nutritional content and antioxidant activity of the product. The use of papaya leaves extract has resulted in a higher protein content, and a stronger antioxidant activity. The utilization of this method would increase $\mathrm{d}$ the potential application of the sea cucumber powder in the formulation of many food and pharmaceutical products. This method of sea cucumber powder preparation with papaya leaves extracts have been practiced by peoples in the sea cucumber production area.

\section{ACKNOWLEDGMENT}

This is to acknowledge to Direktorat Penelitian dan Pengabdian Masyarakat (DRPM) Ditjen Dikti-Ristek, Kemendikbudristek RI, and Universitas Halu Oleo for supporting and funding this study.

\section{REFERENCES}

[1] R. Pangestuti and Z. Arifin, "Medicinal and health benefit effects of functional sea cucumbers," $J$. Tradit. Complement. Med., vol. 8, no. 3, pp. 341351, 2018, doi: 10.1016/j.jtcme.2017.06.007.

[2] E. Pranoto, W. Maruf, and D. Pringgenies, "Kajian aktivitas bioaktif ekstrak teripang pasir (Holothuria Scabra) terhadap jamur Candida albicans," $J$. Pengolah. dan Bioteknol. Has. Perikan., vol. 1, no. 1, pp. 1-8, 2012.

[3] N. M. Putram, I. Setyaningsih, K. Tarman, and M. Nursid, "Anticancer activity from active fraction of sea cucumber," J. Pengolah. Has. Perikan. Indones., vol. 20, no. 1, p. 53, 2017, doi: 10.17844/jphpi.v20i1.16399.

[4] A. S. Sasongko, "Preliminary test of anti Escherichia coli and Staphylococcus aureus bacterium from sea cucumber (Holothuria atra) extracts at Tunda Islands, Serang Regency," Indones. J. Marit. 1(1), 33-38., vol. 1, no. 1, pp. 33-38, 2020.

[5] D. Oktaviani, Y. Mulyani, and E. Rochima, "Aktivitas antioksidan dan antibakteri....," $J$. Perikan. Kelaut., vol. 6, no. 2, pp. 1-6, 2015.

[6] Y. Khotimchenko, "Pharmacological potential of sea cucumbers," Int. J. Mol. Sci., vol. 19, no. 5, pp. 1-42, 2018, doi: 10.3390/ijms19051342.

[7] Meydia, R. Suwandi, and P. Suptijah, "Isolasi senyawa steroid dari teripang gama (Stichopus variegatus) dengan berbagai jenis pelarut," $J . I P B$ JPHPI, vol. 19, no. 3, pp. 362-369, 2016, doi: 10.17844/jphpi.2016.19.3.363.

[8] T. D. Suryaningrum, "teripang: Potensinya sebagai bahan NUTRACEUTICAL dan TEKNOLOGI 
PENGOLAHANNYA," Squalen Bull. Mar. Fish. Postharvest Biotechnol., vol. 3, no. 2, p. 63, 2008, doi: 10.15578/squalen.v3i2.160.

[9] A. Ansharullah and A. B. Patadjai, "Application of Sea Cucumber ( Holothuria scabra ) Powder in the Formulation of Sago Based Biscuit," vol. 62, no. $11,2020$.

[10] R. Latief, A. Laga, and S. Alang, "Studi Pembuatan Tepung Teripang Dari Bahan Baku

[11] Teripang Pasir (Holothuria Scabra) Dengan Perlakuan Perbedaan Konsentrasi Garam Dan Perbedaan Lama Perebusan," Canrea J. Food Technol. Nutr. Culin. J., pp. 1-10, 2018, doi: 10.20956/canrea.v1i1.27.

[12] R. Karnila, M. Astawan, Sukarno, and T. Wresdiyati, "Analisis kandungan nutrisi daging dan tepung teripang pasir (Holothuria scabra J.) segar," Berk. Perikan. Terubuk, vol. 39, no. 2, pp. 51-60, 2011.

[13] Y. Sudrajat, "Teknik penghilangan lapisan kapur pada teripang pasir menggunakan enzim papain," Bul. Tek. Pertan., vol. 7, no. 2, pp. 41-43, 2002.

[14] AOAC, Official Methods of Analysis, 18th ed. Washington DC: Association of Official Analytical Chemists, 2005.

[15] Archana Banerjee, N. Dasgupta, and Bratati De, "In vitro study of antioxidant activity of Syzygium cumini fruit," Food Chem., vol. 90, no. 4, 2005, doi:

https://doi.org/10.1016/j.foodchem.2004.04.033.

[16] P. Molyneux, "The use of the stable free radical diphenylpicrylhydrazyl (DPPH) for estimating antioxidant activity," Songklanakarin J. Sci. Technol., vol. 26, no. 2, pp. 211-219, 2004.

[17] Y. Zhong, M. A. Khan, and F. Shahidi, "Compositional characteristics and antioxidant properties of fresh and processed sea cucumber (Cucumaria frondosa)," J. Agric. Food Chem., vol. 55, no. 4, pp. 1188-1192, 2007.

[18] J. A. Wafa, T. K. Adi, A. Hanapi, and A. G. Fasya, "Penentuan kapasitas antioksidan dan kandungan fenolik total ekstrak kasar teripang pasir (Holothuria scabra) dari Pantai Kenjeran Surabaya," Alchemy, vol. 3, no. 1, pp. 76-83, 2014.
[19] N. Inayah, R. Ningsih, and T. K. Adi, "Uji toksisitas dan identifikasi awal golongan senyawa aktif ekstrak etanol dan n-heksana teripang pasir (Holothuria scabra) kering Pantai Kenjeran Surabaya," Alchemy, vol. 2, no. 1, pp. 92-100, 2012.

[20] E. R. E. Mojica and F. E. Merca, "Isolation and parsial characterization of a lectin from the internal organs of the sea cucumber (Holothuria scabra J)," Int. J. Zool. Res., vol. 1, no. 1, pp. 59-65, 2005.

[21] V. A. Stonik, "Some terpenoid and steroid derivatives from echinoderms and sponges,"Pure Appl. Chem., vol. 58, no. 3, pp. 423-436, 1986.

[22] Y. Kariya, S. Watabes, K. Hashimoto, and K. Yoshida, "Occurrence of chondroitin sulfate $\mathrm{E}$ in glycosaminoglycan isolated from the body wall of sea cucumber Stichopus juponicus. 1990; 265 (9):5081-5085.," J. Biol. Chem., vol. 265, no. 9, pp. 5081-5085, 1990.

[23] O. Y. Althunibat, R. B. Hashim, M. Taher, J. M. Daud, M.-A. Ikeda, and B. Zali, "In vitro antioxidant and antiproliferative activities of three malaysian sea cucumber species," Eur J Sci Res, vol. 373, no. 3, pp. 376-387, 2009. 